\title{
The potential of agroforestry to reduce atmospheric greenhouse gases in Canada: Insight from pairwise comparisons with traditional agriculture, data gaps and future research
}

\author{
by Mark Baah-Acheamfour ${ }^{1}$, Scott X. Chang ${ }^{1}$, Edward W. Bork ${ }^{2}$ and Cameron N. Carlyle ${ }^{2 *}$
}

\begin{abstract}
Canadian agriculture is a source of greenhouse gases (GHG) and agroforestry has the potential to sequester carbon (C), and mitigate agricultural GHG emissions. Agroforestry systems are common features in Canada's agricultural landscape; however, there are limited empirical data to support implementation of agroforestry practices for GHG mitigation. This shortfall of data may be a contributing factor to the lack of policy that supports the use of agroforestry for GHG mitigation in the Canadian agricultural landscape. We reviewed published studies that compared C stocks in vegetation and soils, and/or GHG emissions in agroforestry systems to traditional agriculture across Canada, with the aims of assessing the benefit of adopting agroforestry for GHG reduction. We then identified data gaps and obstacles that could direct future research. We found that most studies reported increases in vegetation and soil organic $\mathrm{C}$ storage in areas with woody species compared to herbaceous crops. Agroforestry systems also reduced the emission of $\mathrm{CH}_{4}$ and $\mathrm{N}_{2} \mathrm{O}$, and increased $\mathrm{CO}_{2}$ respiration from soil, but few studies have examined these gases. The small set of studies we reviewed demonstrated the potential of agroforestry to store terrestrial C and mitigate GHG emissions. However, additional research is required to verify this pattern across geographic regions, determine the regional potential for development of agroforestry systems, and assess the potential atmospheric GHG reduction at regional and national scales.
\end{abstract}

Keywords: carbon flux, methane, mitigation, nitrous oxide, soil carbon

\section{RÉSUMÉ}

Lagriculture canadienne est une source de gaz à effet de serre (GES) et l'agroforesterie pourrait bien contribuer à piéger le carbone $(\mathrm{C})$ et ainsi atténuer les émissions de GES dorigine agricole. L’agroforesterie fait partie intégrante du paysage agricole canadien; on trouve cependant peu de données empiriques permettant d'appuyer l'utilisation de pratiques agroforestières comme moyen d’atténuer les GES. Ce manque de données pourrait expliquer la rareté des politiques encourageant la pratique de l'agroforesterie comme moyen pour atténuer les GES sur la scène agricole canadienne. Nous avons analysé la documentation existante qui compare les stocks de carbone dans la végétation et les sols ou les émissions de GES dans les systèmes agroforestiers à ceux de l'agriculture traditionnelle au Canada en vue dévaluer les avantages de l'agroforesterie comme moyen de réduire les GES. Nous avons ensuite déterminé les données qui manquent ainsi les autres obstacles qui pourraient faire l'objet de recherches dans l'avenir. Nous avons constaté que la plupart des études consultées rapportent un niveau plus élevé de carbone organique stocké dans la végétation et le sol sur les étendues boisées que sur celles couvertes d'herbacé. L'agroforesterie réduit aussi les émissions de $\mathrm{CH}_{4}$ et de $\mathrm{N}_{2} \mathrm{O}$ et augmente le $\mathrm{CO}_{2}$ venant de la respiration du sol même si peu détudes se sont penchées sur ces gaz. Le corpus limité détudes que nous avons consultées montre sans équivoque que lagroforesterie peut stocker le carbone terrestre et atténuer les émissions de GES. Il reste que d’autres études seront nécessaires pour vérifier que cette tendance peut être généralisée à l’ensemble des régions géographiques, établir le potentiel agroforestier de chaque région et évaluer le potentiel de réduction des GES atmosphériques à léchelle régionale et nationale.

Mots-clés: flux de carbone, méthane, atténuation, oxyde nitreux, carbone du sol

\footnotetext{
${ }^{1}$ Department of Renewable Resources, University of Alberta, 442 Earth Science Building, Edmonton, Alberta, Canada T6G 2E.

${ }^{2}$ Department of Agricultural, Food and Nutritional Science, University of Alberta, 410 Agriculture/Forestry Centre, Edmonton, Alberta, Canada T6G 2H1. *Corresponding author: cameron.carlyle@ualberta.ca
} 


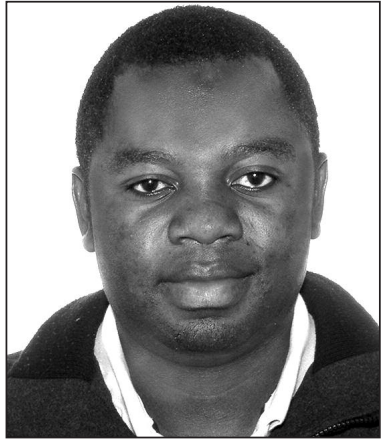

Mark Baah-Acheamfour

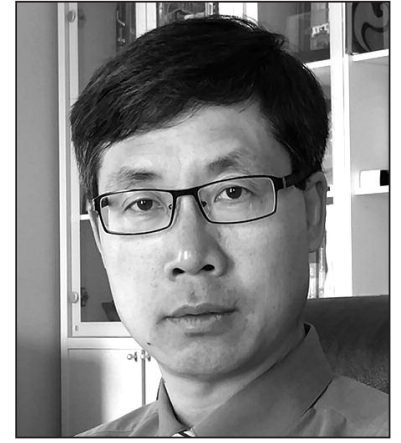

Scott X. Chang

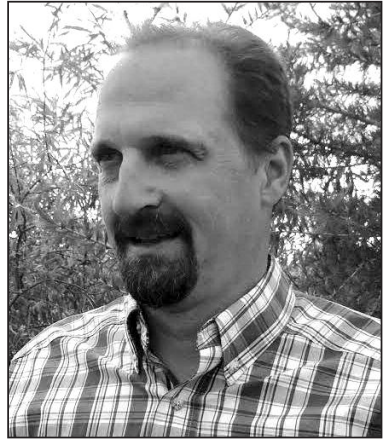

Edward W. Bork

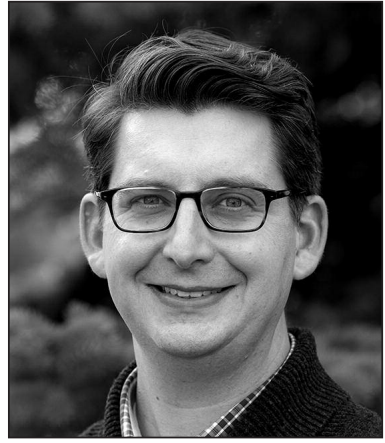

Cameron N. Carlyle

\section{Introduction}

Atmospheric increases in greenhouse gases (GHG) from anthropogenic activities contribute to climate change (IPCC 2013). Canadian agriculture is a significant source of GHG (Liebig et al. 2005, Kebreab et al. 2006); in 2012, Canada contributed $552 \mathrm{Mt}$ of carbon dioxide $\left(\mathrm{CO}_{2}\right), 91 \mathrm{Mt} \mathrm{CO}$-eq. (carbon dioxide equivalent), methane $\left(\mathrm{CH}_{4}\right)$, and $48 \mathrm{Mt}$ of $\mathrm{CO}_{2}$ eq. nitrous oxide $\left(\mathrm{N}_{2} \mathrm{O}\right)$ to the atmosphere, for a total of 691 Mt $\mathrm{CO}_{2}$-eq. and agricultural $\mathrm{GHG}$ emissions were $56 \mathrm{Mt}$ $\mathrm{CO}_{2}$-eq., which accounted for $8 \%$ of total national emissions (Environment Canada 2013). These emissions could be reduced through changes in management practices (Paustian et al. 1998, Desjardins et al. 2001, Duncan 2008). Planting or maintaining woody plant species through agroforestry practices is one possible mechanism to increase carbon (C) capture and reduce GHG emissions from the agricultural landscape (Albrecht and Kandji 2003, Montagnini and Nair 2004, Gordon and Thevathasan 2005, Nair et al. 2009, IPCC 2013), but these practices are not being newly implemented in Canada.

Agroforestry is a land management practice where trees and/or shrubs are deliberately combined with crops or livestock as a way of increasing ecological function and sustainability (Schroeder 1994, Young 1997, Schoeneberger 2009). Agroforestry systems can take many forms, such as alley cropping, windbreak/shelterbelt, natural hedgerow, silvopasture, and riparian buffer systems (Table 1). While these systems are not unique to specific regions in Canada, they may be more widespread in some areas than others, depending on edaphic conditions, climate, and history. Across the Canadian prairies, common agroforestry systems include shelterbelts, hedgerows, and silvopasture (Kort and Turnock, 1999, Kort et al. 2014), while alley cropping is common in Eastern Canada (Thevathasan and Gordon 1997, Oelbermann et al. 2004, Oelbermann et al. 2006, Thevathasan et al. 2012).

The inclusion of trees in croplands and pasturelands through agroforestry practices could lead to reduced atmospheric GHG through a number of mechanisms. First, trees provide greater above- and below-ground biomass compared to herbaceous vegetation and almost $50 \%$ of the dry mass is $\mathrm{C}$ (Aalde et al. 2006). Second, trees increase the total fine root production, rhizo-deposition, and litter-fall, which can all promote organic C sequestration in soil (Montagnini and Nair 2004, Nair et al. 2009). Finally, the system may not only increase total ecosystem $\mathrm{C}$ storage, but also reduce emissions of GHGs such as $\mathrm{CH}_{4}$ and $\mathrm{N}_{2} \mathrm{O}$ from soils (Kang et al. 1999, Dougherty et al. 2009, Evers et al. 2010, Bergeron et al. 2011, Amadi et al. 2016, Baah-Acheamfour et al. 2016, Kim et al. 2016). However, while there have been studies on $C$ sequestration and GHG emissions in agroforestry systems we lack the ability to reliably predict the impact of agroforestry on the net changes in overall $\mathrm{C}$ sequestration and GHG emissions at a national scale because of variation in types of systems and the climatic gradients in which they occur. Our primary objective was to identify and summarize studies that compare agricultural areas that use agroforestry to those that do not, in order to demonstrate whether agroforestry is broadly beneficial to C storage and GHG emissions in Canada. Our second objective was to then identify information gaps that could help direct future research and better verify the use of agroforestry as a means to reduce GHG in Canada.

\section{Data collection and analysis}

We summarized available studies in peer-reviewed literature on $\mathrm{C}$ sequestration and mitigation of GHG emissions in agroforestry systems that occur in Canada. We sought published research on the subject by searching Web of Science on February $25^{\text {th }}, 2017$ using the keywords "carbon storage", "carbon sequestration", "carbon stocks", "carbon dioxide", "methane", "nitrous oxide", "greenhouse gas(es)", "GHG", "soil organic carbon", and "SOC" in combination with each of the following terms for different types of agroforestry systems "shelterbelt", "windbreak", "alley crop", "alley cropping”, "hedgerow", "silvopasture", "riparian", "intercrop", "intercropping" and "agroforestry", and we also included "Canada". This search yielded 125 papers, which were evaluated for inclusion in our review.

A number of criteria were applied to papers for inclusion. First, the study had to be located in Canada. Second, studies had to report on C stocks and/or GHG emissions and contrast between areas with and without trees. This omitted a number of studies from our data review; for example, there were a number of studies on riparian buffer-strips that were not included because they lacked a direct comparison between the buffer-strip and adjacent agricultural land.

In order to maintain independence within our analysis, we removed some studies that were done at the same study sites. For example, extensive research has been done at the University of Guelph's Agroforestry Research Station and our literature search returned Thevathasan et al. (2004), Peichl et al. 
Table 1. Major agroforestry system types in Canada and their main functions

\begin{tabular}{|c|c|c|}
\hline & Description & Functions \\
\hline Alley cropping & Cultivation of crops between rows of trees & $\begin{array}{l}\text { Enhance or diversify farm products } \\
\text { Reduce water runoff and erosion } \\
\text { Protect growing plants } \\
\text { Decrease nutrient or chemical loss } \\
\text { Increase carbon storage in plant biomass and soils }\end{array}$ \\
\hline Windbreak/Shelterbelt & $\begin{array}{l}\text { Rows of planted trees and shrubs along } \\
\text { the margins of agricultural lands }\end{array}$ & $\begin{array}{l}\text { Enhance crop yield } \\
\text { Protect wind-sensitive crops and human developments } \\
\text { Increased crop and animal production } \\
\text { Control erosion } \\
\text { Distribute snowfall } \\
\text { Increase carbon storage in plant biomass and soil }\end{array}$ \\
\hline Hedgerow & $\begin{array}{l}\text { Naturally growing trees, shrubs, and } \\
\text { underlying herbaceous vegetation along } \\
\text { the margins of agricultural lands }\end{array}$ & $\begin{array}{l}\text { Increase biodiversity } \\
\text { Create wildlife habitat } \\
\text { Distribute snowfall } \\
\text { Increase carbon storage in plant biomass and soil }\end{array}$ \\
\hline Silvopasture & $\begin{array}{l}\text { Trees growing irregularly or planted in a } \\
\text { systematic pattern on rangeland or pastures }\end{array}$ & $\begin{array}{l}\text { Provide diversification of crops in time and space } \\
\text { Create wildlife habitat } \\
\text { Provide shelter for livestock } \\
\text { Increase carbon storage in plant biomass and soil }\end{array}$ \\
\hline Riparian forest buffer & $\begin{array}{l}\text { A combination of trees, shrubs, and grass } \\
\text { buffers on the banks of streams, rivers, } \\
\text { wetlands and lakes }\end{array}$ & $\begin{array}{l}\text { Provide economic diversification either through plant } \\
\text { production or recreational fees } \\
\text { Ameliorate non-point source pollution from adjacent landuse } \\
\text { Protect watershed and stream banks } \\
\text { Enhance aquatic and terrestrial habitats } \\
\text { Filtering nutrient runoff }\end{array}$ \\
\hline
\end{tabular}

(2006) and Wotherspoon et al. (2014) which all reported on the same study sites, and so only data from the most recent publication was used.

We included data on $\mathrm{C}$ stored in vegetation (trees, crops and any other herbaceous plants), the size of soil $\mathrm{C}$ stock, and the potential to reduce $\mathrm{CO}_{2}, \mathrm{CH}_{4}$ and $\mathrm{N}_{2} \mathrm{O}$ emissions from only 10 publications in this review. There are undoubtedly other published studies and white papers that report values of C storage and GHG reduction in Canada, which could be compared to data which comes solely from traditional agriculture. But our approach reduces the bias that comes from handpicking papers and the pairwise comparison within studies helps to account for methodological differences between studies and ecosite differences between different locations.

Variation in data handling and terminology among studies required us to make decisions on data presentation and terminology. Most studies reported values by individual sites (e.g., Oelberman 2006, Wotherspoon et al. 2014) while a few studies reported averages on multiple sites (e.g., BaahAcheamfour et al. 2014, 2016; Thiel et al. 2015). When possible, we have presented data from these studies at the individual site level but we also included those studies that averaged across multiple sites. The way that the addition of trees into the system was examined varied between studies. In studies of tree-based intercropping (TBI), comparisons were typically made between conventional agriculture without trees, and agroforestry where crops and trees were directly integrated and measurements were reported from the conventional field and the TBI. In other studies, the tree and crop component of the agroforestry systems were examined individually; these tended to be studies of shelterbelts or hedgerows where the forested and crop components of the agroforestry system were spatially distinct. In order to address our primary question of whether including trees as part of agricultural systems increases C storage and reduces GHG, we have simply compared measurements in tree-covered areas to measurements in areas without trees. The tree components of agroforestry systems and TBI will be referred to as forest, while non-treed areas will be referred to as herbland which is typically dominated by herbaceous plants.

Different studies reported similar measurements in different units and we transformed the units to enable comparison across studies. Some studies reported woody biomass per tree; these values were multiplied by stand density to obtain a value in $\mathrm{MgC} \mathrm{ha}{ }^{-1}$. All areal values were converted to $\mathrm{Mg} \mathrm{ha}^{-}$ ${ }^{1}$ to allow direct comparison between different studies, and soil gas fluxes were converted to standardized values. Many studies reported SOC (soil organic carbon) to multiple depths or from multiple strata; we only examined the deepest SOC values. When values were reported by strata, we summed the values to achieve a value for the total depth. The single exception to this is Amadi et al. (2016), who reported SOC to 30$\mathrm{cm}$ and $1-\mathrm{m}$ depths. We only used the $30-\mathrm{cm}$ value as all other studies only reported SOC to a depth of 30 or $40 \mathrm{~cm}$. We report standard errors for the calculated means. 
Table 2. Vegetation C stocks (above- and below-ground) of various agroforestry systems and nearby herbland in different locations

\begin{tabular}{|c|c|c|c|c|c|c|c|}
\hline \multirow[b]{2}{*}{$\begin{array}{l}\text { Agroforestry } \\
\text { system }\end{array}$} & \multirow[b]{2}{*}{ Location } & \multirow[b]{2}{*}{$\begin{array}{l}\text { Age } \\
\text { (years) }\end{array}$} & \multirow[b]{2}{*}{ Cover type } & \multirow[b]{2}{*}{ Species type } & \multicolumn{2}{|c|}{ Vegetation $\mathrm{C}\left(\mathrm{Mg} \mathrm{ha}^{-1}\right)$} & \multirow[b]{2}{*}{ References } \\
\hline & & & & & $\begin{array}{l}\text { Above- } \\
\text { ground }\end{array}$ & $\begin{array}{l}\text { Below- } \\
\text { ground }\end{array}$ & \\
\hline \multirow[t]{6}{*}{ Alley Cropping } & \multirow[t]{6}{*}{ Ontario } & \multirow[t]{6}{*}{25} & \multirow[t]{5}{*}{ Forest } & Hybrid Poplar & 21.1 & 5.9 & \multirow[t]{6}{*}{ Wotherspoon et al. (2014) } \\
\hline & & & & Norway Spruce & 9.5 & 3.5 & \\
\hline & & & & Red oak & 11.8 & 4.2 & \\
\hline & & & & Black walnut & 12.3 & 2.7 & \\
\hline & & & & White cedar & 16.0 & 4.8 & \\
\hline & & & Herbland & Rotational crop & 0.7 & 0.7 & \\
\hline \multirow[t]{2}{*}{ Shelterbelt } & \multirow[t]{2}{*}{ British Columbia } & \multirow[t]{2}{*}{38} & Forest & Red cedar-mix & 95 & 31 & \multirow[t]{2}{*}{ Theiel et al. $2015^{\star}$} \\
\hline & & & Herbland & Rotational crop & 0 & 0 & \\
\hline \multirow[t]{2}{*}{ Hedgerow } & \multirow[t]{2}{*}{ British Columbia } & \multirow[t]{2}{*}{38} & Forest & Red alder -mix & 60 & 22 & \multirow[t]{2}{*}{ Theiel et al. 2015} \\
\hline & & & Herbland & Rotational crop & 0 & 0 & \\
\hline
\end{tabular}

*Authors described this system as a "planted hedgerow" which matches our definition of a shelterbelt

\section{Carbon stored in vegetation in agroforestry systems}

Agroforestry practices are thought to be ideal for long-term increase in vegetation $C$ because woody species remain in the ground while cropping or grazing is practiced around them. The addition of perennial woody vegetation into these systems is important because of the contribution of $\mathrm{C}$ stored in vegetation and through increased contributions to soil $\mathrm{C}$ through litter fall and root exudates.

In the papers we examined, the forested areas had more $\mathrm{C}$ in above- and below-ground plant biomass $(42.8 \pm 16 \mathrm{Mg} \mathrm{C}$ $\mathrm{ha}^{-1}, \mathrm{n}=7$ ) than herblands (1.4 $\mathrm{Mg} \mathrm{C} \mathrm{ha}^{-1} \mathrm{n}=1$ ) (Table 2). Even in forested areas, vegetation only held $31 \%$ of C; the majority was SOC while root biomass C accounted for $8 \%$ and above-ground biomass for $23 \%$. Our reported plant biomass in herblands may be low because one study, (Theil et al. 2015), only measured woody biomass and the other study adjusted for crop removal (Wotherspoon et al. 2014). Many herbaceous systems can grow more biomass. For example, brome pastures can produce $12.5 \mathrm{Mg} \mathrm{C} \mathrm{ha}^{-1} \mathrm{y}^{-1}$ above ground and almost as much in roots (Bolinder et al. 2002), but these values are still small compared to tree biomass. As one would expect, not all agroforestry systems contain the same amount of $\mathrm{C}$ in vegetation. The single study reporting tree biomass in shelterbelts had $95 \mathrm{Mg} \mathrm{C} \mathrm{ha}^{-1}$ in above-ground vegetation and $31 \mathrm{Mg} \mathrm{C} \mathrm{ha}^{-1}$ below ground, while hedgerows had $60 \mathrm{Mg} \mathrm{C}$ $\mathrm{ha}^{-1}$ above ground and $22 \mathrm{Mg} \mathrm{Cha}^{-1}$ below (Thiel et al. 2015). Tree-based intercropping held $14.1 \pm 2 \mathrm{Mg} \mathrm{C} \mathrm{ha}^{-1}(\mathrm{n}=5)$ in above-ground biomass and $4.2 \pm 0.5 \mathrm{Mg} \mathrm{C} \mathrm{ha}^{-1}(\mathrm{n}=5)$ below ground (Table 2). Riparian buffer strips can also store large amounts of $\mathrm{C}$ in vegetation; for example, up to $63.7 \mathrm{Mg} \mathrm{C} \mathrm{ha}$ ${ }^{1}$ was found in riparian forests in Ontario (Hazlett et al. 2005) but no studies on riparian buffer strips met the criteria of our review.

Methodological difficulties in the estimation of vegetation $\mathrm{C}$ and the extent of ecosystem $\mathrm{C}$ storage are present in all agroforestry systems (Udawatta and Jose 2011). For example, measurements of ecosystem $\mathrm{C}$ within silvopastures are influenced by the lack of reliable estimates of the amount of grass and forest understory vegetation consumed by grazing animals. Large amounts of biomass can be consumed by animals and could be a significant loss of $\mathrm{C}$ from silvopastures (Follett and Kimble 2000); however, animals also redistribute biomass through defecation (Sharrow and Ismail 2004). Furthermore, grazing can affect ecosystem $\mathrm{C}$ by altering vegetation types and microclimate (Macdonald et al. 2015). In Canada, there is information on the impact of grazing on biomass $\mathrm{C}$ in grasslands (e.g., Naeth et al. 1991, Baron et al. 2002), but we found no studies that examine silvopastures specifically. Further, large variability may exist among management practices and sampling methodologies. For example, trees in alley cropping systems may be pruned but the fate of this biomass, which could be left in the system or removed, is likely important to the overall carbon balance (Oelbermann et al. 2006, Wotherspoon et al. 2014). In order to fully understand the potential benefits of agroforestry to $\mathrm{C}$ storage in biomass, a complete accounting of inputs and outputs of biomass is required.

\section{Soil C stored in agroforestry systems}

The earth's soils contain $2400 \mathrm{Pg}$ of SOC in the top $2 \mathrm{~m}$, which is more $\mathrm{C}$ than all terrestrial vegetation and the atmosphere combined (Paustian et al. 1998, Watson et al. 2002). The soil organic C pool is 3.1 times that of the atmospheric pool $(770 \mathrm{Pg})$ and four times the size of the vegetation pool (610 Pg) (Lal 2001). The soil is an important pool of $\mathrm{C}$ because $\mathrm{C}$ stored in above- and below-ground biomass is susceptible to loss by fire or other surface disturbances, while soil $\mathrm{C}$ can be more stable and represents long-term $\mathrm{C}$ storage, provided it is not disturbed by tillage or other processes (Laganiere et al. 2013, Baah-Acheamfour et al. 2014, 2015). Agroforestry has the potential to increase SOC because trees and understory vegetation within agroforestry systems alter the above- and below-ground productivity of agro-ecosystems, modify rooting depth and root distribution, and increase litter-fall, all of which may in turn alter local ecological conditions (Jose 2009). Increases in organic matter can promote processes that lead to SOC accumulation such as humification, soil aggregation, and re-distribution of $\mathrm{C}$ into lower soil layers by deep-rooted trees (Nair 2011). While deep-rooting trees allow more $\mathrm{C}$ to be deposited in deeper 
Table 3. Soil carbon storage of different agroforestry systems and nearby herblands in different locations

\begin{tabular}{|c|c|c|c|c|c|c|c|}
\hline $\begin{array}{l}\text { Agroforestry } \\
\text { system }\end{array}$ & Location & $\begin{array}{l}\text { Age } \\
\text { (years) }\end{array}$ & $\begin{array}{l}\text { Cover } \\
\text { type }\end{array}$ & Species & $\begin{array}{l}\text { Depth } \\
(\mathrm{cm})\end{array}$ & $\begin{array}{l}\text { Soil C } \\
\left(\mathrm{Mg} \mathrm{ha}^{-1}\right)\end{array}$ & References \\
\hline \multirow[t]{14}{*}{ Alley cropping } & \multirow[t]{8}{*}{ Ontario } & \multirow[t]{6}{*}{25} & \multirow[t]{5}{*}{ Forest } & Hybrid poplar & $0-40$ & 86.8 & \multirow[t]{6}{*}{ Wotherspoon et al. (2014) } \\
\hline & & & & Norway spruce & - & 78.3 & \\
\hline & & & & Red oak & - & 83.8 & \\
\hline & & & & Black walnut & - & 83.3 & \\
\hline & & & & White cedar & - & 76.8 & \\
\hline & & & Herbland & Crop rotation & - & 71.1 & \\
\hline & & \multirow[t]{2}{*}{13} & Forest & Hybrid poplar & $0-40$ & 125.4 & \multirow[t]{2}{*}{ Oelbermann et al. (2006 } \\
\hline & & & Herbland & Crop rotation & $0-40$ & 120.3 & \\
\hline & \multirow[t]{6}{*}{ Quebec } & \multirow[t]{2}{*}{8} & Forest & Hybrid poplar - mix & $0-30$ & 77.1 & \multirow[t]{2}{*}{ Bambrick et al. (2010) } \\
\hline & & & Herbland & Crop rotation & - & 43.5 & \\
\hline & & \multirow[t]{4}{*}{9} & Forest & Hybrid poplar & $0-30$ & 85.6 & \multirow[t]{4}{*}{ Winans et al. (2014) } \\
\hline & & & Herbland & Crop rotation & - & 113.2 & \\
\hline & & & Forest & Hybrid poplar & - & 85.7 & \\
\hline & & & Herbland & Crop rotation & - & 101.0 & \\
\hline \multirow[t]{6}{*}{ Shelterbelt } & \multirow[t]{6}{*}{ Saskatchewan } & \multirow[t]{2}{*}{41} & Forest & Scots pine - mix & $0-30$ & 77 & \multirow[t]{6}{*}{ Amadi et al. (2016) } \\
\hline & & & Herbland & Crop rotation & - & 52 & \\
\hline & & \multirow[t]{2}{*}{40} & Forest & Jack pine - mix & - & 108 & \\
\hline & & & Herbland & Crop rotation & - & 93 & \\
\hline & & \multirow[t]{2}{*}{41} & Forest & White spruce - mix & - & 132 & \\
\hline & & & Herbland & Crop rotation & - & 90 & \\
\hline \multirow{2}{*}{$\begin{array}{l}\text { Shelterbelts, } \\
\text { silvopastures } \\
\text { and hedgerows }\end{array}$} & \multirow[t]{2}{*}{ Alberta } & \multirow[t]{2}{*}{ various } & Forest & Variable & $0-30$ & 208 & \multirow[t]{2}{*}{ Baah-Acheamfour (2015) } \\
\hline & & & Herbland & Crop rotation/pasture & - & 15 & \\
\hline
\end{tabular}

soil layers, tillage-induced burial of crop residues at the bottom of the plow-pan in annual croplands may also help sequester $\mathrm{C}$ in deep soil layers (Lacoste et al. 2016).

In our review, $70 \%$ of $\mathrm{C}$ was held in SOC in forested areas (the remaining $30 \%$ was in vegetation) and forested areas held SOC (95 $\left.\pm 8.3 \mathrm{Mg} \mathrm{C} \mathrm{ha}^{-1}, \mathrm{n}=17\right)$ while herblands held $(86.3$ $\pm 8.2 \mathrm{Mg} \mathrm{C} \mathrm{ha}^{-1}, \mathrm{n}=13$ ) (Table 3). There appears to be more variation between studies than between forested and herbaceous areas; in forested areas, SOC ranged from 66.9 to 208 $\mathrm{Mg} \mathrm{C} \mathrm{ha}^{-1}$ across studies but on average the difference within studies was only about $10 \%$. This indicates that location and climatic variables may play a more important role in total SOC than land-use itself. However, due to the small number of studies and variation in sampling depth $(30$ or $40 \mathrm{~cm}$ ) among studies, comparisons between different agroforestry systems are difficult. One study reported greater SOC in herbland than in the agroforestry system, which was attributed to the incorporation of crop residues into soils (Winans et al. 2014). Among agroforestry systems, hedgerows held the most carbon in the soil (106.5 $\left.\mathrm{Mg} \mathrm{C} \mathrm{ha}^{-1}, \mathrm{n}=1\right)$, followed by shelterbelts $\left(98.4 \pm 14 \mathrm{Mg} \mathrm{C} \mathrm{ha}^{-1}, \mathrm{n}=6\right)$ and then tree-based intercropping (83.6 $\pm 4 \mathrm{Mg} \mathrm{C} \mathrm{ha}^{-1}, \mathrm{n}=11$ ) (Table 3).

There were two obstacles we noted while summarizing data on soil $\mathrm{C}$ from multiple studies. First, while all of the studies we included reported bulk density, not all papers report this critical variable. Because land-use can affect bulk density (Mann 1986) and the density of soil can affect overall C storage, it is imperative that studies measure bulk density and report SOC on an equivalent mass basis. Measurement of bulk density at shallow depths is relatively easy and inexpensive, requiring no specialized equipment, so we encourage all researchers to measure soil bulk density and report these values in future studies. Secondly, there is variability in sampling depths across studies. We recognize that sampling depth will be study-specific but we advocate for the development and adoption of a set of standardized sampling depths to reduce variation and allow comparisons across studies (Udawatta and Jose 2011), while still allowing individual studies to meet their objectives.

\section{GHG emissions from soil in agroforestry systems}

Many gases contribute to global climate change but the three most important, due to their concentration and global warming potential, are $\mathrm{CO}_{2}, \mathrm{CH}_{4}$ and $\mathrm{N}_{2} \mathrm{O}$ (Kebreab et al. 2006, IPCC 2013). All three of these gases have complex pathways and originate from multiple sources. Carbon dioxide is consumed by plants but also respired by organisms through aerobic respiration, $\mathrm{CH}_{4}$ can be respired but also consumed by microorganisms in the soil depending on environmental conditions and, similarly, $\mathrm{N}_{2} \mathrm{O}$ can be consumed or released through a number of microbial processes. Land-use can affect the soil flux of all three of these GHG. 
Table 4. Net carbon dioxide $\left(\mathrm{CO}_{2}\right)$, methane $\left(\mathrm{CH}_{4}\right)$, and nitrous oxide $\left(\mathrm{N}_{2} \mathrm{O}\right)$ fluxes in forest and herbland cover types in agroforestry systems in Canada. Missing values indicate that the flux of a particular gas was not measured in the study.

\begin{tabular}{|c|c|c|c|c|c|c|c|c|}
\hline $\begin{array}{l}\text { Agroforestry } \\
\text { system }\end{array}$ & Location & $\begin{array}{l}\text { Age } \\
\text { (year) }\end{array}$ & $\begin{array}{l}\text { Cover } \\
\text { type }\end{array}$ & Species & $\begin{array}{l}\mathrm{CO}_{2} \\
\left(\mathrm{MgC}^{-1} \mathrm{y}^{-1}\right)\end{array}$ & $\begin{array}{c}\mathrm{CH}_{4} \\
\left(\mathrm{Kg} \mathrm{C}^{-1}\right. \\
\left.\mathrm{ha}^{-1} \mathrm{y}^{-1}\right)\end{array}$ & $\begin{array}{l}\mathrm{N}_{2} \mathrm{O} \\
\left(\mathrm{g} \mathrm{N}^{\left.\mathrm{ha}^{-1} \mathrm{~d}^{-1}\right)}\right.\end{array}$ & References \\
\hline \multirow[t]{6}{*}{ Alley cropping } & \multirow[t]{4}{*}{ Ontario } & \multirow[t]{4}{*}{25} & Forest & Hybrid poplar & 6.24 & - & - & \multirow[t]{4}{*}{ Wotherspoon et al. (2014) } \\
\hline & & & Forest & Norway spruce & 5.86 & - & - & \\
\hline & & & Forest & Black Walnut & 5.9 & - & - & \\
\hline & & & Herbland & Crop rotation & 4.9 & - & - & \\
\hline & \multirow[t]{2}{*}{ Québec } & \multirow[t]{2}{*}{4} & Forest & & - & - & 5.27 & \multirow{2}{*}{ Beaudette et al. (2010) } \\
\hline & & & Herbland & & - & - & 19.1 & \\
\hline \multirow[t]{6}{*}{ Shelterbelt } & \multirow[t]{6}{*}{ Saskatchewan } & \multirow[t]{2}{*}{41} & Forest & Scots pine - mix & 4.0 & -0.9 & 2.7 & \multirow[t]{6}{*}{ Amadi et al. (2016) } \\
\hline & & & Herbland & Crop rotation & 1.9 & -0.31 & 8.2 & \\
\hline & & \multirow[t]{2}{*}{40} & Forest & Jack pine - mix & 3.0 & -0.2 & 1.4 & \\
\hline & & & Herbland & Crop rotation & 2.3 & -0.15 & 5.8 & \\
\hline & & \multirow[t]{2}{*}{41} & Forest & White spruce - mix & 4.0 & -0.85 & 0.7 & \\
\hline & & & Herbland & Crop rotation & 2.1 & -0.15 & 6.8 & \\
\hline
\end{tabular}

In our review, we found only three studies that met our criteria and reported GHG emissions (Table 4). Because there are so few papers, we have not averaged GHG emissions across studies. Two of these were from alley cropping systems in Eastern Canada and the single study reporting all three gasses was from shelterbelts in Saskatchewan. Total reported $\mathrm{CO}_{2}$ emissions were always greater in forest soils than herbland soils. The increased $\mathrm{CO}_{2}$ emissions from forests is likely due to increased root and microbial respiration (Peichl et al. 2006, Wotherspoon et al. 2014) or a modification in soil micro-environment due to trees (Amadi et al. 2016). However, when net $\mathrm{CO}_{2}$ flux is quantified by taking into account $\mathrm{C}$ assimilation by trees, litter fall $\mathrm{C}$ input, root turnover, crop $\mathrm{C}$ input and output, and $\mathrm{C}$ leaching, forested areas can be a net $\mathrm{CO}_{2}$ sink. In Ontario, TBI, despite having higher $\mathrm{CO}_{2}$ emissions, was a net sink of $13.2 \mathrm{Mg} \mathrm{CO}_{2}-\mathrm{Cha}^{-1}$ year $^{-1}$, while the herbland was a source of $2.9 \mathrm{Mg} \mathrm{CO}_{2}-\mathrm{C} \mathrm{ha}^{-1}$ year $^{-1}$ which was likely due to greater $\mathrm{C}$ assimilation within the tree rows that compensated for high soil respiration and resulted in net sequestration of C compared with the herbland (Peichl et al. 2006). Our review also indicates that agroforestry is beneficial for reducing other GHG. Forested areas, both shelterbelts and tree-based intercrops, had lower $\mathrm{N}_{2} \mathrm{O}$ emissions than herblands (Table 4). Greater $\mathrm{N}_{2} \mathrm{O}$ flux from herblands is due to nitrogen-based fertilizer inputs (Vitousek et al. 1997), thus there has been interest in the use of agroforestry systems to recover nitrates, which could leach into groundwater or contribute to $\mathrm{N}_{2} \mathrm{O}$ emissions (Thevathasan et al. 2004, Dougherty et al. 2009). The roots of trees can assimilate residual nitrate left from nitrogen fertilizer applications. Agroforestry systems that use woody legumes such as caragana (Caragana arborescens Lam.) may increase the supply of mineralizable nitrogen in soils and increase $\mathrm{N}_{2} \mathrm{O}$ emissions. Though this biological addition of nitrogen to the system could reduce the need for fertilizers (Hutchinson et al. 2007), over fertilization in soils could result in the substantial loss of nitrogen in the form of volatilization of ammonia and leaching of nitrates
(Evers et al. 2010), which could lead to an increase in $\mathrm{N}_{2} \mathrm{O}$ emissions from agricultural soils. The single study reporting on methane showed that shelterbelts and cropland soils both consumed methane, but forests consumed more (Table 4). Methane is an important GHG, especially from livestock production. Silvopastures can become a 'hot spot' for $\mathrm{CH}_{4}$ emissions through enteric emissions from livestock (Beauchemin and McGinn 2006, Beauchemin et al. 2010). If woody species can modify the soil micro-environment and enhance $\mathrm{CH}_{4}$ oxidation, then the $\mathrm{CH}_{4}$ uptake will offset emissions from livestock activity, but the net effect depends on the magnitude of uptake in the soil. Based on studies in the prairies, hedgerow, shelterbelt, and silvopastures had greater $\mathrm{CH}_{4}$ uptake rates than adjacent cropped fields (Amadi et al. 2016, Baah-Acheamfour et al. 2016). Greater $\mathrm{CH}_{4}$ uptake in forested areas compared with adjacent cropped fields could be due to reduced soil disturbance, greater soil macroporosity and lower nitrogen-based fertilizer applications in forested areas compared with cropped fields (MacDonald et al. 1997, Mosier et al. 2006, Gacengo et al. 2009). We found no studies from Canada that reported GHG emissions from other agroforestry systems, but studies outside of Canada indicate that riparian buffers consume less methane than cropland (Kim et al. 2008) and release more $\mathrm{CO}_{2}$ (Tufekcioglu et al. 2001).

Overall, studies on GHG emissions in Canadian agroforestry systems are few but these studies suggest that the impact of woody species on the emission of these gases in agriculture may be significant. The total GHG global warming potential of forested soils is less than herbland soils (BaahAcheamfour et al. 2016), but it is worth noting that many other factors contribute to the net gas flux of these systems: land-use, fossil fuel combustion, biomass burning, tillage, harvesting, manure addition, and livestock production (Dixon 1995). Future studies on GHG emissions in agroforestry will need to consider the GHG flux of the entire agricultural system. 


\section{Data gaps and future research needs}

Results of this review are encouraging for the potential of agroforestry to store C and mitigate GHG emissions. However, efforts to encourage the use of agroforestry for GHG reduction in Canada have suffered from the lack of effective policy mechanisms that tie these systems, either through their creation or maintenance, to future $\mathrm{C}$ sequestration and $\mathrm{GHG}$ mitigation. These barriers occur at different levels of organization, from individual farms to government policy, and research outcomes.

Anecdotal evidence suggests that shelterbelts and hedgerows are removed in the Canadian prairies as producers create space for larger farm equipment to maneuver, and the need for soil conservation through windbreaks has declined with the adoption of reduced tillage methods of growing annual crops. Personal communications by the authors with producers suggest that an additional contributing factor is the practice does not provide immediate benefits or revenue to landowners. This observation is corroborated by a study in southern Ontario in which the loss of income due to a reduction of the insurable crop area was a reason for producers to not adopt agroforestry (Simpson 1999). Trees can also compete with neighboring crops (Reynolds et al. 2007) or understory forage species in silvopasture systems (Powell and Bork 2006, 2007; LaRade and Bork 2011). Long-term adoption of agroforestry systems has been lower than expected in many regions of Canada (Matthews et al. 1993, Kulshreshtha 2010) and it is unlikely that farmers will create new or maintain existing agroforestry systems unless they are proven to be more profitable. Initial tree establishment costs, combined with the loss of revenue due to removing cropland from production, often deter Canadian farmers from adopting agroforestry (Valdivia et al. 2012). The structure of agriculture in Canada has changed over the last two decades toward larger farms that benefit from economy of scale, which often incorporate rented lands (Statistics Canada 2011). Large farm operations may not undertake activities such as tree planting that do not generate immediate revenue or if the market value is less than that of traditional cropping (Toor et al. 2012), and owners of rented land may see the land as a revenue source and be less inclined to environmental stewardship and conservation compared to landowners who farm their own land.

Federal and provincial governments could play a role in supporting agroforestry. However, in recent years the federal government has removed some of its support for such programs. For example, farmers in the provinces of Alberta, Saskatchewan, and Manitoba no longer have access to the Prairie Shelterbelt Program which was terminated by the federal government in 2013. The Prairie Shelterbelt Program was established under the Prairie Farm Rehabilitation Act (PFRA) to assist farmers in dealing with the prolonged drought of the 1930s (PFRA 2000). The program enabled conservation measures and diversification of prairie agriculture through the provision of trees and shrub seedlings to prairie farmers (Mackay et al. 1999). These changes will likely lead to a decline in the total coverage of agroforestry across Canada and a reduction or loss of some of the environmental goods and services that these systems provide.

Policy and incentives could encourage the adoption of agroforestry systems in Canada. Carbon markets could pay landowners for $\mathrm{C}$ sequestration as an environmental service (Aldy and Stavins 2012, Crossman et al. 2012, Alam et al.
2014). However, society's willingness to pay for $C$ sequestration has yet to be clearly established, but recent policy announcements by both provincial and the federal governments to implement carbon taxes may provide market mechanisms. Alberta was the first province to implement a carbon market through a modified combined carbon tax and capand-trade system (AARD 2015). This market requires emitters to pay a levy on emissions (currently valued at $\$ 20$ tonne${ }^{1} \mathrm{CO}_{2}$-eq. and set to rise to $\$ 30$ tonne ${ }^{-1} \mathrm{CO}_{2}$-eq. in 2018). At the same time, there are a number of protocols that enable payments for practices that reduce GHG. While many of these protocols are related to agricultural practices, payment for $C$ sequestered through tree retention or established on agricultural lands is still under revision (AARD 2015) and will rely, in part, on credible data highlighting the benefits of agroforestry systems in reducing atmospheric GHG. The value of such a policy to landowners has not been determined, but a recent study found that landowners in Quebec could be eligible for $\mathrm{C}$ payments up to $\$ 2758 \mathrm{CAD} \mathrm{ha}^{-1}$ after 10 years of alley cropping based on only $\$ 11.39$ tonne ${ }^{-1} \mathrm{CO}_{2}$ eq. (Winans et al. 2016). Others have placed the value of climate regulation by tree-based intercropping at \$ $357 \mathrm{ha}^{-1}$ year $^{-1}$ based on a carbon cost of $\$ 43$ per tonne (Alam et al. 2014). Adoption of policy that offsets $C$ through agroforestry could benefit landowners through revenue diversification and society through atmospheric GHG reduction. However, for policy that supports $\mathrm{C}$ sequestration through agroforestry to be implemented, credible data verifying agroforestry as a practice to reduce atmospheric GHG is required.

We identified a number of research needs when studying agroforestry systems for the purpose of understanding their contribution to reducing GHGs and sequestering C. Research that does a full accounting of biomass within the system, studies the effects of environmental variability on relevant ecological processes, reports standardized measurements (e.g., bulk density and soil depths), and performs a full accounting of GHG within the entire system through a lifecycle assessment, will help to better quantify the overall benefit of agroforestry for GHG reduction. An additional research need is the quantification of the spatial area occupied by agroforestry systems in Canada. Though agroforestry is practiced across the country, there are few estimates of the total land area currently used for agroforestry or where agroforestry could be successfully implemented. Thevathasan et al. (2012) estimated the linear dimension of shelterbelts across Canada (excluding British Columbia) to be 0.3 million $\mathrm{km}$, one third of which occurs within Alberta, Saskatchewan, and Manitoba. A more comprehensive assessment estimated the total length of shelterbelts in Saskatchewan to be 45231 $\mathrm{km}$ (Amichev et al. 2015), while just $991 \mathrm{~km}$ of spruce shelterbelts in Saskatchewan are estimated to have sequestered 50 $440 \mathrm{Mg}$ C over the past 80 years (Amichev et al. 2016). Thorough estimates of the spatial extent of different types of agroforestry, including estimates of areas where agroforestry could be newly practiced, will help estimate the potential total reduction of GHG by agroforestry. Finally, there are only a few published papers from western Canada and while there are more published papers from Ontario and Quebec, they were done at a limited number of locations. Broader geographic representation combined with a spatial assessment of agroforestry systems will enable estimates of the national benefit for GHG reduction resulting from agroforestry. 


\section{Conclusions}

Agroforestry systems are land-use systems that maintain and often increase $\mathrm{C}$ storage and contribute to GHG mitigation in agricultural landscapes. Across multiple studies we found that agroforestry increased vegetative $\mathrm{C}$, soil organic carbon (SOC) stocks, and soil $\mathrm{CO}_{2}$ emissions, but reduced $\mathrm{CH}_{4}$ and $\mathrm{N}_{2} \mathrm{O}$ emissions compared to cropland. Despite increased $\mathrm{CO}_{2}$ emissions, agroforestry systems can be net $\mathrm{C}$ sinks. However, the size of the $\mathrm{C}$ stock and emissions via soil respiration can vary, depending on the type of agroforestry system employed, plant species composition, edaphic and climatic conditions, system age, and management intensity. More research examining different types of agroforestry systems across more geographic regions is needed to demonstrate that agroforestry systems have the capacity to sequester $\mathrm{C}$ and reduce $\mathrm{GHG}$ emissions across all of Canada's agricultural areas. Finally, integrating the results of these studies in a meaningful way with policy could provide incentives to farmers and facilitate the adoption of these systems helping Canada to meet its GHG reduction targets.

\section{Acknowledgements}

The authors gratefully thank Agriculture and Agri-Food Canada (AAFC) for its financial support through the Agricultural Greenhouse Gas Program (AGGP) that funded the research in this review paper. Two anonymous reviewers provided comments that improved this manuscript.

\section{References}

Aalde, H., P. Gonzalez, M. Gytarsky, T. Krug, W. Kurz, et al. 2006. Forest land. In: 2006 IPCC Guidelines for National Greenhouse Gas Inventories, Volume 4 (Agriculture, Forestry and Other Land Use). IPCC, Published by the Institute for Global Environmental Strategies (IGES), Hayama, Japan, on behalf of the IPCC, pp. 1-4.

AARD. 2015. Agricultural carbon offsets: Information for Alberta's offset market [Online] Available from http://worldwidewords.agriculture. alberta.ca/agcarbonoffsets [accessed 10 November 2015]. Alam, M., A. Olivier, A. Paquette, J. Dupras, J.P. Reveret and C. Messier. 2014. A general framework for the quantification and valuation of ecosystem services of tree-based intercropping systems. Agroforest. Syst. 88: 679-691. DOI 10.1007/s10457-014-9681-x

Albrecht, A. and S.T. Kandji. 2003. Carbon sequestration in tropical agroforestry systems. Agric. Ecosyst. Environ. 99: 15-27.

Aldy, J.E. and R.N. Stavins. 2012. The promise and problems of pricing carbon: Theory and experience. J. Environ. Dev. 21: 152-180. Amadi, C.C., K.C. Van Rees and R.E. Farrell. 2016. Soil-atmosphere exchange of carbon dioxide, methane and nitrous oxide in shelterbelts compared with adjacent cropped fields. Agric. Ecosyst. Environ. 223: 123-134.

Amichev, B.Y., M.J. Bentham, W.A. Kurz, C.P. Laroque, S. Kulshreshtha, J.M. Piwowar and K.C. Van Rees. 2016. Carbon sequestration by white spruce shelterbelts in Saskatchewan, Canada: 3PG and CBM-CFS3 model simulations. Ecol. Model. 325: 35-46.

Amichev, B.Y., M.J. Bentham, D. Cerkowniak, J. Kort, S. Kulshreshtha, C.P. Laroque, J.M. Piwowar and K.C. Van Rees. 2015. Mapping and quantification of planted tree and shrub shelterbelts in Saskatchewan, Canada. Agrofor. Syst. 89: 49-65.

Baah-Acheamfour, M., C.N. Carlyle, E.W. Bork and S.X. Chang. 2014. Trees increase soil carbon and its stability in three agroforestry systems in central Alberta, Canada. For. Ecol. Manage. 328: 131-139. Baah-Acheamfour, M., S.X. Scott, C.N. Carlyle and E.W. Bork. 2015. Carbon pool size and stability are affected by trees and grassland cover types within agroforestry systems of western Canada. Agric. Ecosyst. Environ. 213: 105-113.
Baah-Acheamfour, M., C.N. Carlyle, S.S. Lim, E.W. Bork and S.X. Chang. 2016. Forest and grassland cover types reduce net greenhouse gas emissions from agricultural soils. Sci. Total Environ. doi: 10.1016/j.scitotenv.2016.07.106

Bambrick, A.D., J.K. Whalen, R.L. Bradley, A. Cogliastro, A.M. Gordon, A. Olivier and N.V. Thevathasan. 2010. Spatial heterogeneity of soil organic carbon in tree-based intercropping systems in Quebec and Ontario, Canada. Agrofor. Syst. 79: 343-353.

Baron, V.S., E. Mapfumo, A.C. Dick, M.A. Naeth, E.K. Okine and D.S. Chanasyk. 2002. Grazing intensity impacts on pasture carbon and nitrogen flow. J. Range Manage. 55: 5 35-541.

Beaudette, C., R.L. Bradley, J.K. Whalen, P.B.E. McVetty, K. Vessey and D.L. Smith. 2010. Tree-based intercropping does not compromise canola (Brassica napus L.) seed oil yield and reduces soil nitrous oxide emissions. Agric. Ecosyst. Environ. 139: 33-39.

Beauchemin, K.A. and S.M. McGinn. 2006. Enteric methane emissions from growing beef cattle as affected by diet and level of intake. Can. J. Anim. Sci. 86: 401-408.

Beauchemin, K.A., H.H. Janzen, S.M. Little, T.A. McAllister and S.M. McGinn. 2010. Life cycle assessment of greenhouse gas emissions from beef production in western Canada: A case study. Agr. Syst. 103: 371-379.

Bergeron, M., S. Lacombe, R.L. Bradley, J.Whalen, A. Cogliastro, M. Jutras and P. Arp. 2011. Reduced soil nutrient leaching following the establishment of tree-based intercropping systems in eastern Canada. Agrofor. Syst. 83: 321-330.

Bolinder, M. A., D. A. Angers, G. Belanger, R. Michaud and M.R. Laverdiere. 2002. Root biomass and shoot to root ratios of perennial forage crops in eastern Canada. Can. J. Plant Sci. 82: 731-737.

Crossman, N.D., B. Burkhard and S. Nedkov. 2012. Quantifying and mapping ecosystem services. Int. J. Biodivers. Sci. Ecosyst. Serv. Manage. 8: 1-4.

Desjardins, R., S. Kulshreshtha, B. Junkins, W. Smith, G. Grant and M. Boehm. 2001. Canadian greenhouse gas mitigation options in agriculture. Nutr.Cycl.Agroecosyst. 60: 317-326.

Dixon, R.K. 1995. Agroforestry systems: Sources or sinks of greenhouse gases? Agrofor. Syst. 31: 99-116.

Dougherty, M.C., N.V. Thevathasan, A.M. Gordon, L. Lee and J. Kort. 2009. Nitrate and Escherichia coli NAR analysis in tile drain effluent from a mixed tree intercrop and monocrop system. Agric. Ecosyst. Environ. 131: 77-84.

Duncan, K. 2008. Agricultural practices that reduce greenhouse gases (GHGs) and generate co-benefits. Environ. Toxicol. 110: 61-69. Environment Canada. 2013. Canada's emission trend. [online] http://www.ec.gc.ca/indicateurs-indicators/default.asp?lang=en\&n= CCED3397-1 [accessed 18 May 2014].

Evers, A.K., A. Bambrick, S. Lacombe, M.C. Dougherty, M. Peichl, N.V Thevathasan, J. Whalen and R.L. Bradley. 2010. Potential greenhouse gas mitigation through temperate tree-based intercropping systems. Open Agric. J. 4: 49-57.

Follett, R.F. and J.M. Kimble. 2000. The potential of US grazing lands to sequester carbon and mitigate the greenhouse effect. CRC Press.

Gacengo, G.N., C.W. Wood, J.H. Shaw, R.L. Raper and K.S. Balkcom. 2009. Agroecosystem management effects on greenhouse gas emissions across a coastal plain catena. Soil Sci. 174: 229-237.

Gordon, A.M. and N.V. Thevathasan. 2005. How much carbon can be stored in Canadian agroecosystems using a silvopastoral approach? In: Mosquera-Losada MR., McAdams J., RigueiroRodriquez A. (eds.) Silvopasture and Sustainable Land Manage, $\mathrm{I}^{\text {st }}$ ed. CABI Publishing, Wallingford, 210-217 p.

Hazlett, P.W., A.M. Wood, P.K. Sibley and J.M. Buttle. 2005. Stand carbon stocks and soil carbon and nitrogen storage for riparian and upland forests of boreal lakes in northeastern Ontario. Forest. Ecol. Manag. 219: 56-58.

Hutchinson, J.J., C.A. Campbell and R.L. Desjardins. 2007. Some perspectives on carbon sequestration in agriculture. Agric. For. Meteorol. 142: 288-302. 
IPCC. 2013. Climate change: The physical science basis. Working group I contribution to the fifth assessment report of the Intergovernmental Panel on Climate Change. Stocker, T.F., D. Qin, G.-K. Plattner, M. Tignor, S.K. Allen, J. Boschung, A. Nauels, Y. Xia, V. Bex and P.M. Midgley (eds.). Cambridge University Press, United Kingdom.

Jose, S. 2009. Agroforestry for ecosystem services and environmental benefits: An overview. Agrofor. Syst. 76: 1-10.

Kang, B.T., F.E. Caveness, G. Tian and G.O. Kolawole. 1999. Longterm alley cropping with four hedgerow species on an Alfisol in southwestern Nigeria - effect on crop performance, soil chemical properties and nematode population. Nutr. Cycl. Agroecosyst. 54: $145-155$.

Kebreab, E., K. Clark, C. Wagner-Riddle and J. France. 2006. Methane and nitrous oxide emissions from Canadian animal agriculture: A review. Can. J. of Anim. Sci. 86: 135-158.

Kim, D.G., M.U. Kirschbaum and T.L. Beedy. 2016. Carbon sequestration and net emissions of $\mathrm{CH}_{4}$ and $\mathrm{N}_{2} \mathrm{O}$ under agroforestry: Synthesizing available data and suggestions for future studies. Agric. Ecosyst. Environ. 226: 65-78.

Kim, D.G., T.M. Isenhart, T.B. Parkin, R.C. Schultz and T.E. Loynachan. 2008. Methane flux in cropland and adjacent riparian buffers with different vegetation covers. J. Env. Qual. 39: 97-105.

Kort, J. and R. Turnock. 1999. Carbon reservoir and biomass in Canadian prairie shelterbelts. Agrofor. Syst. 44: 175-186.

Kort, J., J. Richardson, R. Soolanayakanahally and W. Schroeder. 2014. Innovations in temperate agroforestry: the 13th North American Agroforestry Conference. Agrofor. Syst. 88: 563-567.

Kulshreshtha, S.N. 2010. Agroforestry development on the Canadian prairies. Nova Science Publishers.

Laganiere, J., D. Paré, Y. Bergeron, H.Y., Chen, B.W. Brassard and X. Cavard. 2013. Stability of soil carbon stocks varies with forest composition in the Canadian boreal biome. Ecosystems 16: 852-865.

Lacoste, M., V. Viaud, D. Michot and C. Walter. 2016. Model $\bowtie$ based evaluation of impact of soil redistribution on soil organic carbon stocks in a temperate hedgerow landscape. Earth. Surf. Process. doi:10.1002/esp.3925.

Lal, R. 2001. World cropland soils as a source or sink for atmospheric carbon. Adv. Agron. 71: 145-191.

LaRade, S.E. and E.W. Bork. 2011. Short Communication: Aspen forest overstory relations to understory production. Can. J. Plant Sci. 91: 847-851.

Liebig, M., J. Morgan, J. Reeder, B. Ellert, H. Gollany and G. Schuman. 2005. Greenhouse gas contributions and mitigation potential of agricultural practices in northwestern USA and western Canada. Soil Tillage Res. 83: 25-52.

Macdonald, C.A., M.J. Crawley, D.J. Wright, J. Kuczynski, L. Robinson, R. Knight, W.A. Al『Soud, S.J. Sørensen, Y. Deng, J. Zhou and B.K. Singh. 2015. Identifying qualitative effects of different grazing types on below冈ground communities and function in a long冈term field experiment. Environ. Microbiol. 17: 841-854.

Macdonald, J., U. Skiba, L. Sheppard, B. Ball, J. Roberts, K. Smith and D. Fowler. 1997. The effect of nitrogen deposition and seasonal variability on methane oxidation and nitrous oxide emission rates in an upland spruce plantation and moorland. Atmos. Environ. 31: 3693-3706.

Mackay, W.C., T.G. Miller, D.R. Moore and R. Woelcke. 1999. Performance characteristics of aeration devices. Prairie Farm Rehabilitation Administration.Prairie Farm Administration Paper, Peace River, AB, Canada.

Mann, L.K. 1986. Changes in soil carbon storage after cultivation. Soil Sci. 142: 279-288.

Matthews, S., S.M. Pease, A.M. Gordon and P.A. Williams. 1993.

Landowner perceptions and the adoption of agroforestry practices in southern Ontario, Canada. Agrofor. Syst. 21: 159-168.
Montagnini, F. and P.K.R. Nair. 2004. Carbon sequestration: An underexploited environmental benefit of agroforestry systems. Agrofor. Syst. 61-2: 281-295.

Mosier, A.R., A.D. Halvorson, C.A. Reule and X.J. Liu. 2006. Net global warming potential and greenhouse gas intensity in irrigated cropping systems in northeastern Colorado. J. Environ. Qual. 35: 1584-1598.

Naeth, M.A., A.W. Bailey, D.J. Pluth, D. Chanasyk and R.T. Hardin. 1991. Grazing impacts on litter and soil organic matter in mixed prairie and fescue grassland ecosystems of Alberta. J. Range Manage. 44: 7-12.

Nair, P.K.R. 2011. Agroforestry systems and environmental quality: Introduction. J. Environ. Qual. 40: 784-790.

Nair, P.K.R., B.M. Kumar and V.D. Nair. 2009. Agroforestry as a strategy for carbon sequestration. J. Plant Nutr. Soil Sci. 172:10-23. Oelbermann, M., P.R. Voroney and A.M. Gordon. 2004. Carbon sequestration in tropical and temperate agroforestry systems: A review with examples from Costa Rica and southern Canada. Agric. Ecosys. Environ. 104: 359-377.

Oelbermann, M., R.P. Voroney, N.V. Thevathasan, A.M. Gordon, D.C.L Kass and A.M. Schlönvoigt. 2006. Soil carbon dynamics and residue stabilization in a Costa Rican and southern Canadian alley cropping system. Agrofor. Syst. 68: 27-36.

Paustian, K., C.V. Cole, D. Sauerbeck and N. Sampson. 1998. $\mathrm{CO}_{2}$ mitigation by agriculture: An overview. Clim. Change 40: 135-162.

Peichl, M., N.V. Thevathasan, A.M. Gordon, J. Huss, R.A. Abohassan. 2006. Carbon sequestration potentials in temperate treebased intercropping systems, Southern Ontario, Canada. Agrofor. Syst. 66: 243-257.

PFRA. 2000. Prairie agricultural landscapes: A land resource review. ISBN 0-622-28574-3. Minister of Public Works and Government Services 2000, 179 p.

Powell, G.W. and E.W. Bork. 2006. Aspen canopy removal and root trenching effects on understory vegetation. Forest. Ecol. Manag. 230: 79-90.

Powell, G.W. and E.W. Bork. 2007. Effects of aspen canopy removal and root trenching on understory microenvironment and soil moisture. Agrofor. Syst. 70: 113-124.

Reynolds, P.E., J.A. Simpson, N.V. Thevathasan and A.M. Gordon. 2007. Effects of tree competition on corn and soybean photosynthesis, growth, and yield in a temperate tree-based agroforestry intercropping system in southern Ontario, Canada. Ecological Engineering 29: 362-371.

Schoeneberger, M.M. 2009. Agroforestry: Working trees for sequestering carbon on agricultural lands. Agrofor. Syst. 75: 27-37.

Schroeder, P. 1994. Carbon storage benefits of agroforestry systems. Agrofor. Syst. 27: 89-97.

Sharrow, S.H. and S. Ismail. 2004. Carbon and nitrogen storage in agroforests, tree plantations, and pastures in western Oregon, USA. Agrofor. Syst. 60: 123-130.

Simpson, J.A. 1999. Effects of shade on maize and soybean productivity in a tree-based intercropping system. $\mathrm{PhD}$ Thesis, University of Guelph, Guelph.

Statistics Canada. 2011. Demographic Changes in Canadian Agriculture. Statistics Canada Catalogue no. 96-325-X. Ottawa. Version updated November 2014. [Online] http://www5.statcan.gc.ca/subject-sujet $/$ result - resultat pid $=920 \& i d=-920 \& l a n g=$ eng $\&$ type $=$ OLC\&pageNum $=1 \&$ more $=0$ [accessed 13 May2015]

Thevathasan, N.V. and A.M. Gordon. 1997. Poplar leaf biomass distribution and nitrogen dynamics in a poplar-barley intercropped system in southern Ontario, Canada. Agrofor. Syst. 37: 79-90.

Thevathasan, N.V., A.M. Gordon, J.A. Simpson, P.E. Reynolds, G. Price and P. Zhang. 2004. Biophysical and ecological interactions in a temperate tree-based intercropping system. J. Crop Improv. 12: 339-363. 
Thevathasan, N.V., A.M. Gordon, R. Bradley, et al. 2012. Agroforestry research and development in Canada: The way forward. In Nair PKR, Garrity DP (eds.). The Future of Global Land Use, Dordrecht, The Netherlands, 247-283 p.

Thiel, B., S. M. Smukler, M. Krzic, S. Gergel and C. Terpsma. 2015. Using hedgerow biodiversity to enhance the carbon storage of farmland in the Fraser River delta of British Columbia. J. Soil Water Conserv. 70: 247-256.

Toor, I. A., E. G. Smith, J.K. Whalen and A. Naseem. 2012. Treebased intercropping in Southern Ontario, Canada. Can. J. Ag. Econ. 60: 141-154.

Tufekcioglu, A., J.W. Raich, T.M. Isenhart and R.C. Schultz. 2001. Soil respiration within riparian buffers and adjacent crop fields. Plant and Soil: 229: 117-124.

Udawatta, R.P. and S. Jose. 2011. Carbon sequestration potential of agroforestry practices in temperate North America. In: Kumar BM, Nair PKR (eds.) Carbon Sequestration Potential of Agroforestry Systems: Opportunities and Challenges. Springer, Dordrecht $42 \mathrm{p}$.

Valdivia, C., C. Barbieri and M.A. Gold. 2012. Between forestry and farming: Policy and environmental implications of the barriers to agroforestry adoption. Can. J. Agric. Econ. 60: 155-175.
Vitousek, P.M., J.D. Aber, R.W. Howarth, G.E. Likens, P.A. Matson, D.W. Schindler, W.H. Schlesinger and D.G. Tilman. 1997. Human alteration of the global nitrogen cycle: sources and consequences. Ecological Applications 7: 737-750.

Watson, C.A., D. Atkinson, P. Gosling, P.L. Jackson and F.W. Rayns. 2002. Managing soil fertility in organic farming systems. Soil Use Manage. 18: 239-247.

Winans, K., J.K. Whalen, A. Cogliastro, D. Rivest and L. Ribaudo. 2014. Soil carbon stocks in two hybrid poplar-hay crop systems in Southern Quebec, Canada. Forests 5: 1952-1966.

Winans, K.S., J.K. Whalen, D. Rivest, A. Cogliastro and R.L. Bradley. 2016. Carbon sequestration and carbon markets for treebased intercropping systems in southern Quebec, Canada. Atmosphere 7: 17 .

Wotherspoon, A., N.W. Thevathasan, A.M. Gordon and R.P. Voroney. 2014. Carbon sequestration potential of five tree species in a 25-year-old temperate tree-based intercropping system in southern Ontario, Canada. Agrofor. Syst. 88: 631-643.

Young, A. 1997. Agroforestry for soil management, $2^{\text {nd }}$ ed. CAB International, Wallingford, UK, 330 p. 